\title{
Knowledge and Attitudes Among Hospital Pharmacists About COVID-19
}

\section{Hastane Eczacılarının COVID-19 Konusunda Bilgi ve Tutumları}

\author{
(D) Emre KARA ${ }^{1 *}$, (D) Kutay DEMIRKAN1ㄴ, (D) Serhat ÜNAL2 \\ ${ }^{1}$ Hacettepe University Faculty of Pharmacy, Department of Clinical Pharmacy, Ankara, Turkey \\ 2Hacettepe University Faculty of Medicine, Department of Infectious Diseases and Clinical Microbiology, Ankara, Turkey
}

\begin{abstract}
Objectives: Coronavirus (COVID-19) cases and deaths related to the virus have been reported all over the world. Pharmacists play an important role in conveying accurate information about COVID-19 to the community. The aim of this study was to evaluate the knowledge and attitudes among hospital pharmacists about COVID-19.

Materials and Methods: A questionnaire was distributed to pharmacists participating in the $7^{\text {th }}$ National Hospital and Institution Pharmacists Congress. The questions included in this questionnaire were created using the Turkish COVID-19 Scientific Committee guideline (COVID-19 Guideline).

Results: Analysis of 237 questionnaires ( $72.6 \%$ completed by women) showed that the media (television, newspaper), internet (nonscientific resources), internet (scientific resources), and social media were the most popular sources of information $(60.3 \%, 53.6 \%, 53.2 \%$, and $41.4 \%$, respectively). The participants' age and the source of information that they used had an important influence on their knowledge of and attitudes towards COVID-19 infection. The majority of the participants (72.6\%) stated that they were not wearing any kind of mask. Transmission of the disease by airborne route was well known by the participants (91.1\%), as well as the main symptoms such as fever ( $92.4 \%)$, cough ( $84.4 \%)$, and dyspnea (60.3\%). The participants were aware of the risk groups for COVID-19 infection such as advanced age (84.8\%) and having comorbidities (80.2\%). Washing hands with soap (92.0\%), using hand disinfectants (80.6\%), and avoiding contact with sick people (81.9\%) were popular answers for protection from the disease, but wearing an N95 mask was also mentioned by $59.1 \%$ of the participants. Prevention of the disease by rinsing the nose with saline solution was believed in by $43.9 \%$ of the participants.

Conclusion: Classical media and social media affect the attitudes of both the public and health professionals. Using media tools for accurate information is one of the basic conditions for preventing and controlling the spread of the disease.
\end{abstract}

Key words: COVID-19, hospital pharmacists, knowledge, attitudes

ÖZ

Amaç: Tüm dünyada Koronavirüs (COVID-19), olguları ve bu hastalığa bağlı ölümler bildirilmiştir. Bir sağık uzmanı olarak eczacılar COVID-19 hakkında doğru bilgilerin topluma iletilmesinde önemli rol üstlenmektedir. Bu çalışmada hastane eczacılarının COVID-19 hakkındaki bilgi ve tutumlarının değerlendirilmesi amaçlanmıștır.

Gereç ve Yöntemler: Çalıșma kapsamında 7. Ulusal Hastane ve Kurum Eczacıları Kongresi'ne katılan hastane eczacılarına bir anket uygulandı. Bu ankette yer alan sorular, Türkiye COVID-19 Bilim Kurulu Kılavuzu (COVID-19 Kılavuzu) kullanılarak oluşturulmuştur.

Bulgular: Çalışmada \%72,6'sı kadın olmak üzere toplam 237 katılımcıya ait anket değerlendirilmiștir. Katıımcıların sırasıyla \%60,3, \%53,6, \%53,2 ve \%41,4'ünün bilgi kaynağı olarak en çok medyayı (televizyon, gazete), internet (bilimsel kaynaklar), interneti (bilimsel olmayan kaynaklar) ve sosyal medyayı kullandığı saptanmıştır. Katılımcıların COVID-19 ile ilgili bilgi ve tutumlarında yaşın ve kullandıkları bilgi kaynaklarının önemli etkisinin olduğu belirlenmiştir. Katılımcıların \%72,6'sı korunma amaçlı cerrahi maske kullanmadığını bildirmiştir. Katılımcıların, hastalığın damlacıkla bulaştığı (\%91,1) ve hastalığın genel semptomları (ateş; \%92,4, öksürük; \%84,4, solunum güçlüğü \%60,3) konularında bilgi sahibi oldukları görülmüştür. Katılımcıların geneli tarafından, ileri yaşın $(\% 84,8)$ ve eşlik eden hastalıkların $(\% 80,2)$ COVID-19 için risk faktörü olduğunun bilindiği saptanmıştır. Hastalıktan korunmak için ellerin sabunla yıkanması $(\% 92,0)$, el dezenfektanı kullanılması $(\% 80,6)$, hasta kișilerle temasın önlenmesi $(\% 81,9)$ sıklıkla belirtilen cevaplar arasında yer alsa da, katıımcıların \%59,1'i N95 maske kullanımının da gerekli olduğunu belirtmiştir. Katılımcıların \%43,9'unun tuzlu su ile burnu yıkamanın, hastalığı önlemede etkili olduğuna inandığı görülmüștür.

Sonuç: Klasik medya ve sosyal medya toplumun ve sağlık profesyonellerinin tutumlarını etkilemektedir. Doğru bilginin sağlanması için medya araçlarını kullanmak, hastalığın yayılmasını önlemek ve kontrol etmek için önemlidir.

Anahtar kelimeler: COVID-19, hastane eczacıları, bilgi, tutum

*Correspondence: E-mail: emrekara@hacettepe.edu.tr, Phone: +90 5060512443 ORCID-ID: orcid.org/0000-0002-7034-4787

Received: 04.04.2020, Accepted: 13.04.2020

๑Turk J Pharm Sci, Published by Galenos Publishing House. 


\section{INTRODUCTION}

In December 2019, a new, severe pneumonia outbreak occurred in Wuhan, China and a new coronavirus was identified as the pathogen responsible. First, this virus was named 2019 Novel Coronavirus and later Severe Acute Respiratory Syndrome Coronavirus-2 (SARS-COV-2), and the disease caused by this virus has been named Coronavirus Disease 2019 (COVID-19).'

Positive cases of COVID-19 and deaths due to this virus have been reported in almost every country in the world. ${ }^{2}$ Coronaviruses are a family of viruses that can cause mild diseases, such as the common cold, and more serious diseases, such as Middle East Respiratory syndrome (MERS) - COV or SARS-COV. SARS-COV-2, which is currently the cause of a pandemic and was the subject of this survey, is a virus from this family. Coronaviruses are mainly zoonotic and can cause disease in humans as a result of transmission from animals. ${ }^{3}$

The most common symptoms of infection are fever, cough, and dyspnea. In more serious cases pneumonia, severe acute respiratory syndrome, kidney failure, and death may develop. ${ }^{4}$ The available data show that the rate of fatal cases is not very high in the young population. ${ }^{5}$ However, older people (over 60 years) and people with comorbidities (such as diabetes and heart disease) may be more vulnerable and mortality can be high in this population. ${ }^{3}$

So far, there is no specific, effective, proven, pharmacological treatment or prophylaxis. Although no vaccine or drug has been developed for this infection, it has been suggested that some existing drugs can be used for treatment. ${ }^{6}$

As healthcare professionals, pharmacists play an important role in conveying accurate information about COVID-19 to the community. The aim of the present study was to evaluate the knowledge and attitudes among hospital pharmacists about COVID-19.

\section{MATERIALS AND METHODS}

A two-page self-structured questionnaire consisting of 22 multiple-choice and/or open-ended questions was distributed to pharmacists participating in the $7^{\text {th }}$ National Hospital and Institution Pharmacists Congress held between 4 and 7 March 2020 in Turkey. The first positive COVID-19 case in Turkey was identified on 10 March 2020, and therefore no known COVID-19 case existed in Turkey during the period of the study. Moreover, none of the presentations at the congress were related to COVID-19 infection. There are 2747 hospital pharmacists in Turkey. ${ }^{7}$ The sample size for this study was calculated as 155 people with an $80 \%$ confidence level and a $5 \%$ margin of error. The questionnaire was distributed to the participants who attended the first session on the $2^{\text {nd }}$ day of the congress. At the end of the session, the questionnaires were collected from the participants.

The questions included in this questionnaire were created using the guideline (COVID-19 Guideline) created by the Turkish COVID-19 Scientific Committee and the COVID-19 information on the Ministry of Health website (https://hsgm.saglik.gov.tr/tr/ bulasici-hastaliklar/2019-n-cov.html).
The questionnaire did not include the first name or surname of the participants, and the data were obtained anonymously. Age, sex, duration (years) of work in the profession, and job title were collected as demographic data. The participants' flu vaccination status was enquired about to evaluate their attitudes on protection from infection. The names of the two coronaviruses that had previously caused significant outbreaks were asked about to understand their interest in the issue (openended questions with no options). Fifteen other multiple-choice questions were asked about sources of information, knowledge, thoughts, and attitudes about COVID-19. The participants were instructed to choose only one answer for some of the questions $(n=4)$ and more than one answer for the others $(n=8)$. There were also 5 true/false questions. "Other" was provided as a choice for each question and an explanation was expected if this option was marked. Answers to the other options are given in brackets in the results.

\section{Statistical analysis}

The results obtained were analyzed using IBM SPSS Statistics for MacOS, version 23.0 (IBM Corp., Armonk, NY, USA). Percentage, average and standard deviation, median, and minimum-maximum were used for the descriptive data. A chisquare test was used to compare categorical variables. A 95\% confidence interval was applied to examine the change in data and $p<0.05$ was considered statistically significant for all tests.

\section{RESULTS}

A total of 550 pharmacists participated in the congress and 440 (80\%) of them were hospital pharmacists. Approximately 300 questionnaires were distributed to participants during the session. The questionnaire was filled out by 268 participants. Thirty one questionnaires were excluded because either the participants were not pharmacists $(n=2)$ or not hospital pharmacists $(n=24)$ or due to incomplete data $(n=5)$. Thus the analysis was performed with a total of 237 questionnaires.

\begin{tabular}{|c|c|c|}
\hline Parameters & & n (\%) \\
\hline \multirow{2}{*}{ Sex } & Female & 172 (72.6) \\
\hline & Male & $65(27.4)$ \\
\hline \multirow{5}{*}{ Age } & $20-29$ years & $80(33.8)$ \\
\hline & 30-39 years & 79 (33.3) \\
\hline & 40-49 years & $54(22.8)$ \\
\hline & $50-59$ years & $18(7.6)$ \\
\hline & $\geq 60$ years & $6(2.5)$ \\
\hline \multirow{4}{*}{$\begin{array}{l}\text { How many years have you } \\
\text { been working? }\end{array}$} & $\langle 5$ years & $74(31.2)$ \\
\hline & $5-10$ years & $48(20.3)$ \\
\hline & $11-20$ years & $62(26.2)$ \\
\hline & 20 years and & $53(22.4)$ \\
\hline
\end{tabular}


The majority of the participants were women ( $n=172,72.6 \%)$ and between the ages of 20 and $39(n=159,67.8 \%)$ (Table 1). Only $6.8 \% \quad(n=16)$ of the participants stated that they were vaccinated for influenza every year and $5.1 \%(n=12)$ stated that they had been vaccinated for influenza this year.

SARS-CoV was given as an answer by 157 (66.2\%) participants and MERS-CoV by $99(41.8 \%)$ to the question "What are the two coronaviruses that previously caused important epidemics?" Other answers were H1N1 (swine flu) ( $n=33,13.9 \%)$, H5N1 (bird flu) ( $n=13,5.5 \%)$, Ebola ( $n=11,4.6 \%)$, Influenza $(n=3,1.3 \%)$, HCoV-229E ( $n=2,0.8 \%), \mathrm{HCoV}-\mathrm{OC} 43(n=1,0.4 \%)$, and H2N2 $(n=1,0.4 \%)$. The majority of the participants (139 out of 232, $59.9 \%$ ) stated that they had a fear of being infected with SARSCoV-2. Only 43 out of 216 (18.1\%) participants reported that there is an effective antiviral drug against COVID-19 disease.

The answers given by participants to the COVID-19 questionnaire are given in Tables 2, 3, and 4.

Participants' knowledge and attitudes towards COVID-19 infection were compared according to the source of information from which they learned about COVID-19 infection and

Table 2. Questions on knowledge about COVID-19 disease

\begin{tabular}{|c|c|c|}
\hline Questions & Answers* & $\mathrm{n}(\%)$ \\
\hline \multirow{8}{*}{$\begin{array}{l}\text { When will the outbreak } \\
\text { end? }(n=222)\end{array}$} & $\begin{array}{l}\text { When the air } \\
\text { temperature rises }\end{array}$ & $87(39.2)$ \\
\hline & Within 1-2 months & $34(15.3)$ \\
\hline & 6 months to 1 year & $66(29.7)$ \\
\hline & Within $1-2$ years & $18(8.1)$ \\
\hline & Within 2-5 years & $10(4.5)$ \\
\hline & Within $5-10$ years & $1(0.5)$ \\
\hline & After 10 years & $3(1.4)$ \\
\hline & Other (it will not end) & $3(1.4)$ \\
\hline \multirow{5}{*}{$\begin{array}{l}\text { What is the first source of } \\
\text { the infection? }(n=212)\end{array}$} & It is not known clearly & $112(52.8)$ \\
\hline & Bats & $78(36.8)$ \\
\hline & Pangolins & $19(9.0)$ \\
\hline & Humans & $3(1.4)$ \\
\hline & Camels & $0(0.0)$ \\
\hline \multirow{4}{*}{$\begin{array}{l}\text { How long is the incubation } \\
\text { period of the disease? } \\
(n=220)\end{array}$} & <2 days & $2(0.9)$ \\
\hline & 2-14 days & $176(80.0)$ \\
\hline & $15-28$ days & $41(18.6)$ \\
\hline & $>28$ days & $1(0.5)$ \\
\hline \multirow{5}{*}{$\begin{array}{l}\text { What is the mortality rate } \\
\text { from COVID-19? }(n=209)\end{array}$} & $0-1 \%$ & $21(10.0)$ \\
\hline & $1.1-5 \%$ & $127(60.8)$ \\
\hline & $5.1-10 \%$ & $45(21.5)$ \\
\hline & $10.1-25 \%$ & $13(6.1)$ \\
\hline & $>25 \%$ & $3(1.4)$ \\
\hline
\end{tabular}

*: Only one option was chosen, COVID: Coronavirus Disease statistically significant findings were detected only regarding the issues given below.

When the attitudes of 'the participants that obtained information through social media' and 'those that did not' were compared, statistically significant differences were determined in the following:

- Their behavior regarding wearing a mask in crowded environments ( $14.5 \%$ and $5.3 \%$, respectively; $p=0.016$ );

- Their knowledge about transmission of the disease through kissing $(61.2 \%$ and $43.9 \%$, respectively; $p=0.012)$ and through blood (19.4\% and $8.6 \%$, respectively; $p=0.019)$;

- Their knowledge of prevention of the disease by rinsing the nose with saline solution $(54.1 \%$ and $36.7 \%$, respectively; $\mathrm{p}=0.011)$ and eating mulberry molasses $(7.1 \%$ and $1.4 \%$, respectively; $p=0.035$ );

- Their belief in protection from the disease by wearing N95 masks (69.4\% and $51.8 \%$, respectively; $p=0.007$ ), protective eyeglasses $(32.7 \%$ and $18.0 \%$, respectively; $p=0.015)$, and medical gloves (48.0\% and $31.7 \%$, respectively; $p=0.014$ ).

When the attitudes of 'the participants that used the internet (scientific resources) as an information source' and 'those that did not' were compared, statistically significant differences were detected in the following:

- Their belief in transmission of COVID-19 by shipments from China (42.7\% and 58.9\%, respectively; $p=0.021$ );

- Their behavior in protection from the disease by washing hands more than before $(91.3 \%$ and $77.5 \%$, respectively; $\mathrm{p}=0.004$ ), wearing a mask on public transport ( $11.9 \%$ and $2.7 \%$, respectively; $p=0.012)$, wearing a mask while traveling $(14.3 \%$ and $5.4 \%$, respectively; $p=0.030$ ), and wearing a mask in crowded environments $(15.9 \%$ and $1.8 \%$, respectively; $p<0.001)$. However, respectively $62.7 \%$ and $83.8 \%$ of the participants stated that they were not wearing a mask at all $(p<0.001)$.

Table 3. The approach of the participants to true/false knowledge questions about COVID-19

\begin{tabular}{lcc} 
Proposal & True, $n$ (\%) & False, $n$ (\%) \\
\hline $\begin{array}{l}\text { Coronaviruses are zoonotic viruses, } \\
\text { mainly causing infection in animals } \\
(n=228)\end{array}$ & $161(70.6)$ & $67(29.4)$ \\
\hline $\begin{array}{l}\text { COVID-19 is a vaccine-preventable } \\
\text { disease ( } n=226)\end{array}$ & $102(45.1)$ & $124(54.9)$ \\
\hline $\begin{array}{l}\text { COVID-19 can be treated with } \\
\text { antiretroviral drugs ( } n=223)\end{array}$ & $109(48.9)$ & $114(51.1)$ \\
\hline $\begin{array}{l}\text { In this country, the necessary facilities } \\
\text { are available to diagnose COVID-19 } \\
(n=229)\end{array}$ & $160(69.9)$ & $69(30.1)$ \\
\hline
\end{tabular}

There is a possibility of SARS-COV-2 infection from packages or products from China $(n=230)$

89 (38.7) $\quad 141(61.3)$

COVID: Coronavirus Disease, SARS-COV-2: Severe Acute Respiratory Syndrome Coronavirus-2 
Table 4. Questions on knowledge and attitudes about COVID-19 disease

\begin{tabular}{|c|c|c|}
\hline Questions & Answers* & $\mathrm{n}(\%)$ \\
\hline \multirow{9}{*}{$\begin{array}{l}\text { From which } \\
\text { source(s) did } \\
\text { you learn about } \\
\text { COVID-19? }\end{array}$} & Media (TV, newspaper) & $143(60.3)$ \\
\hline & Internet (nonscientific resources) & $127(53.6)$ \\
\hline & Internet (scientific resources) & $126(53.2)$ \\
\hline & Social media & $98(41.4)$ \\
\hline & Educational/scientific meeting & $66(27.8)$ \\
\hline & Friends/family & $30(12.7)$ \\
\hline & Courses & $2(0.8)$ \\
\hline & I did not get information & $1(0.4)$ \\
\hline & Other (ministry announcements) & $1(0.4)$ \\
\hline \multirow{8}{*}{$\begin{array}{l}\text { Do you wear } \\
\text { a mask for } \\
\text { COVID-19? }\end{array}$} & I do not & $172(72.6)$ \\
\hline & While traveling & $24(10.1)$ \\
\hline & In crowded environments & $22(9.3)$ \\
\hline & In the workplace & $21(8.9)$ \\
\hline & On public transport & $18(7.6)$ \\
\hline & While walking in the streets & $1(0.4)$ \\
\hline & I always wear one & $1(0.4)$ \\
\hline & Every time I leave home & $0(0.0)$ \\
\hline \multirow{6}{*}{$\begin{array}{l}\text { In which way(s) } \\
\text { is COVID-19 } \\
\text { transmitted? }\end{array}$} & It is transmitted by airborne route & $216(91.1)$ \\
\hline & Kissing & $121(51.1)$ \\
\hline & Shaking hands & $89(37.6)$ \\
\hline & It is transmitted by blood & $31(13.1)$ \\
\hline & By sexual intercourse & $23(9.7)$ \\
\hline & $\begin{array}{l}\text { From mother to baby during } \\
\text { childbirth }\end{array}$ & $21(8.9)$ \\
\hline \multirow{10}{*}{$\begin{array}{l}\text { What is the } \\
\text { symptom(s) of } \\
\text { the infection? }\end{array}$} & Fever & $219(92.4)$ \\
\hline & Cough & $200(84.4)$ \\
\hline & Dyspnea & $143(60.3)$ \\
\hline & Pneumonia & $91(38.4)$ \\
\hline & Runny nose & $64(27.0)$ \\
\hline & Sudden loss of consciousness & $24(10.1)$ \\
\hline & Diarrhea & $15(6.3)$ \\
\hline & Kidney failure & $10(4.2)$ \\
\hline & Bleeding & $4(1.7)$ \\
\hline & Other (nausea) & $1(0.4)$ \\
\hline \multirow{6}{*}{$\begin{array}{l}\text { Who is more } \\
\text { affected by } \\
\text { COVID-19? }\end{array}$} & Elderly & $201(84.8)$ \\
\hline & $\begin{array}{l}\text { People with comorbidities such } \\
\text { as asthma, diabetes, and heart } \\
\text { disease }\end{array}$ & $190(80.2)$ \\
\hline & Children & $70(29.5)$ \\
\hline & Pregnant women & $48(20.3)$ \\
\hline & Young adults & $7(3.0)$ \\
\hline & $\begin{array}{l}\text { Other (immunocompromised } \\
\text { individuals) }\end{array}$ & $2(0.8)$ \\
\hline
\end{tabular}

Table 4. Continue

\begin{tabular}{|c|c|c|}
\hline \multirow{9}{*}{$\begin{array}{l}\text { Which should be } \\
\text { applied to protect } \\
\text { from COVID-19? }\end{array}$} & Washing hands with soap & $218(92.0)$ \\
\hline & Avoiding contact with sick people & $194(81.9)$ \\
\hline & Using hand disinfectant & $191(80.6)$ \\
\hline & Wearing an N95 mask & $140(59.1)$ \\
\hline & Wearing medical gloves & $91(38.4)$ \\
\hline & Wearing a surgical mask & 89 (37.6) \\
\hline & $\begin{array}{l}\text { Covering the nose and mouth } \\
\text { with tissue paper }\end{array}$ & $82(34.6)$ \\
\hline & Wearing protective eyeglasses & $58(24.5)$ \\
\hline & Wearing protective clothing & $58(24.5)$ \\
\hline \multirow{8}{*}{$\begin{array}{l}\text { Which can } \\
\text { prevent } \\
\text { COVID-19? }\end{array}$} & $\begin{array}{l}\text { Rinsing the nose with saline } \\
\text { solution }\end{array}$ & $104(43.9)$ \\
\hline & Using vinegar & $51(21.5)$ \\
\hline & Using ginger & $24(10.1)$ \\
\hline & Using turmeric & $23(9.7)$ \\
\hline & Using echinacea & $22(9.3)$ \\
\hline & Eating mulberry molasses & $9(3.8)$ \\
\hline & Using pomegranate peel & $7(3.0)$ \\
\hline & $\begin{array}{l}\text { Other (alkaline disinfectants, } \\
\text { vaccination, vitamin C, drinking } \\
\text { plenty of liquid, ethanol, drinking } \\
\text { warm water, black elderberry, } \\
\text { sheep's head and foot soup, } \\
\text { cologne, propolis) }\end{array}$ & $12(5.1)$ \\
\hline \multirow{7}{*}{$\begin{array}{l}\text { What actions do } \\
\text { you perform to } \\
\text { protect against } \\
\text { COVID-19? }\end{array}$} & $\begin{array}{l}\text { I wash my hands more than } \\
\text { before }\end{array}$ & $201(84.8)$ \\
\hline & $\begin{array}{l}\text { I try to touch less frequently } \\
\text { where other people touch }\end{array}$ & $172(72.6)$ \\
\hline & $\begin{array}{l}\text { I try to stay away from people } \\
\text { coughing }\end{array}$ & $153(64.6)$ \\
\hline & I go to shopping malls less & $113(47.7)$ \\
\hline & $\begin{array}{l}\text { I reduce my use of public } \\
\text { transportation }\end{array}$ & $106(44.7)$ \\
\hline & $\begin{array}{l}\text { I participate less in indoor } \\
\text { activities such as theater and } \\
\text { cinema }\end{array}$ & $84(35.4)$ \\
\hline & $\begin{array}{l}\text { I cancel meetings and activities } \\
\text { with my friends }\end{array}$ & $40(16.9)$ \\
\hline
\end{tabular}

*: More than one option was chosen, COVID: Coronavirus Disease

Statistically significant differences were also detected in the comparison of the attitudes and knowledge of 'the participants that obtained information from family/friends' and 'those that did not' in some points such as:

- Their knowledge about prevention of the disease by eating mulberry molasses ( $13.3 \%$ and $2.4 \%$, respectively; $p=0.017$ );

- Their knowledge on the protective role of wearing a surgical mask $(66.7 \%$ and $33.3 \%$, respectively; $p=0.001)$, protective eyeglasses ( $40.0 \%$ and $22.2 \%$, respectively; $p=0.042$ ), and protective clothing $(50.0 \%$ and $20.8 \%$, respectively; $\mathrm{p}=0.001)$. 
When the attitudes of 'the participants that obtained information from educational/scientific meetings' and 'those that did not' were compared, statistically significant differences were detected in their knowledge about the protective role of washing hands ( $98.5 \%$ and $89.5 \%$, respectively; $p=0.029$ ) and wearing a surgical mask (51.5\% and $32.2 \%$, respectively; $p=0.007$ ).

When attitudes of 'the participants that used the Internet (nonscientific resources) to obtain information about COVID-19' and 'those that did not' were compared, statistically significant differences were determined in their knowledge on transmission of the disease through kissing ( $57.5 \%$ and $43.6 \%$, respectively; $\mathrm{p}=0.038$ ).

When the attitudes of 'the participants under the age of 40 years' and 'the participants over the age of 40 years' were compared, statistically significant differences were detected in some points such as their belief in the protective role of echinacea $(13.2 \%$ and $1.3 \%$, respectively; $p=0.002)$, sexual transmission of the infection ( $13.8 \%$ and $1.3 \%$, respectively; $p=0.002)$, and transmission of the infection from mother to baby at birth (13.2\% and $0 \%$, respectively; $p<0.001)$.

When the attitudes of 'the participants that believe COVID-19 is transmitted by airborne route' and 'those that do not' were compared, statistically significant differences were determined only in the following:

- Their belief in protection from the disease by washing hands with soap $(96.8 \%$ and $42.9 \%$, respectively; p $<0.001)$, using hand disinfectants $(84.3 \%$ and $42.9 \%$, respectively; p $<0.001)$, avoiding contact with sick people $(86.1 \%$ and $38.2 \%$, respectively; p $<0.001)$, wearing an N95 mask ( $64.8 \%$ and $0 \%$, respectively; $p<0.001)$, wearing medical gloves $(41.7 \%$ and $4.8 \%$, respectively; $\mathrm{p}=0.001$ ), and wearing protective clothing (26.4\% and $4.8 \%$, respectively; $p=0.031$ );

- Their knowledge on prevention of the disease by rinsing the nose with saline solution $(46.8 \%$ and $14.3 \%$, respectively; $p=0.005$ );

- Their actions that they implemented to protect against COVID-19 infection such as

- canceling meetings and activities with friends (18.5\% and $0 \%$, respectively; $p=0.029$ ),

- reducing public transportation use $(47.7 \%$ and $14.3 \%$, respectively; $\mathrm{p}=0.005$ ),

- minimizing shopping mall visits $(51.4 \%$ and $9.5 \%$, respectively; $p<0.001$,

- minimizing indoor activities such as theater and cinema ( $38.4 \%$ and $4.8 \%$, respectively; $p=0.001$ ),

o trying to stay away from people coughing $(68.5 \%$ and $23.8 \%$, respectively; $p<0.001$ ),

- trying to touch less frequently where other people touch ( $76.9 \%$ and $28.6 \%$, respectively; $p<0.001$ ),

- washing hands more than before $(89.8 \%$ and $33.3 \%$, respectively; $p<0.001$ ).

\section{DISCUSSION}

Providing information about drugs to patients, caregivers, and healthcare professionals is one of the main responsibilities of all pharmacists. ${ }^{8}$ These days, as the number of positive cases of COVID-19 continues to increase in this country, healthcare professionals must have accurate and reliable information to be able inform the public properly. Health professionals have important roles in reducing the sense of panic in the community, encouraging individuals to take measures without panic, and convincing them to continue their lives by taking precautions. ${ }^{9}$

At the end of January, a survey was conducted to evaluate the knowledge, attitudes, and practices among the public in China. More than half of the participants included in that study were living in the Hubei region, where the disease first appeared. Correct answers were given to $70.2 \%$ to $98.6 \%$ of the questions about COVID-19. People between the ages of 30 and 49, those with higher educational status (master's degree and above), and students gave more right answers to the questions. The rate of wearing a mask and level of knowledge were significantly higher in participants living in Hubei.10 By the time the survey was conducted, many people in China had been diagnosed with COVID-19 infection and many had died from it. However, when the questionnaire was applied in our study, no positive COVID-19 case had been diagnosed in Turkey. The first positive case was detected 5 days later and then more educational/informational programs organized by the Ministry of Health were shown in the media for public awareness.

According to available data, close contacts, droplets, and aerosol were defined as transmission routes of COVID-19.1 In our study, almost all of the participants stated that it was transmitted by airborne route. Some common traditional behaviors in Turkish society such as hugging and kissing (on the cheeks or the hands of the elderly) are risky sources of close contact and can cause disease transmission..$^{12}$ The participants also mentioned handshaking and kissing as transmission routes.

In the present study, the participants generally used the media, Internet, and social media as resources. The source of information that the participants used to learn about COVID-19 infection had an important influence on their knowledge of and attitudes towards COVID-19 infection. The participants that used the Internet (scientific resources) as an information source had the right approaches especially in actions for protection from the disease (such as washing hands more than ever and wearing a mask on public transport, while traveling, and in crowded environments). The participants that obtained information from educational/scientific meetings also had the right approaches concerning protection from the disease (such as washing hands and wearing a surgical mask). However, those that obtained information from family/friends had the wrong approaches mainly regarding prevention of the disease (such as eating mulberry molasses) and protection from the disease (such as wearing protective eyeglasses and protective clothing). The participants that received information through social media had incorrect approaches, especially concerning the transmission of the disease (such as through blood), prevention of the disease (such as rinsing the nose with saline and eating mulberry molasses), and protection from the disease (such as wearing an N95 mask, protective eyeglasses, and medical gloves). It is recommended that an N95 mask be worn 
by healthcare workers and surgical/medical masks should be worn by patients with respiratory symptoms in public."

Some misleading information such as rinsing the nose with saline or consumption of some foods or products (e.g., vinegar, echinacea, and mulberry molasses) has been proposed by either some physicians or some prominent people on TV programs in Turkey. Even though these statements were criticized and corrected by other physicians and experts, some of the participants' preference for these methods (especially rinsing the nose with saline solution) reveals the strong influence of the media.

In the present study, it was detected that age is another factor that influences the participants' knowledge of and attitudes towards COVID-19 infection. The participants under the age of 40 had the wrong approaches especially regarding the protective role of echinacea and transmission routes of the disease (such as sexually and from mother to baby at birth).

SARS-CoV and MERS-CoV diseases were known about by approximately half of the participants, meaning that half of the participants were not interested in this issue. The majority of the participants believed that the pandemic would end when the air temperature rose or within 6 months to 1 year. In the study by Zhong et al. ${ }^{10}, 91 \%$ of the participants indicated that COVID-19 would be successfully controlled. In the studies conducted in the SARS-CoV epidemic, most of the participants (70.1-88.9\%) stated that the epidemic would be successfully controlled. The fact that rapid restrictive measures were taken in the SARSCoV epidemic and COVID-19 pandemic in China may be the source of this trust. While it is often thought that the first source of infection is unknown, bats was the answer given most by the participants. In our study, the incubation period was known correctly by almost all of the participants as stated by Chinese guidelines (average 7 days, ranging from 2 to 14 days). ${ }^{13}$

Although mortality rates vary between countries, almost all the respondents stated a mortality rate of $1-10 \%$ in the present study, which is generally correct. The case-fatality rate was found to be $2.3 \%$ in a wide-ranging assessment in China. ${ }^{14}$ The average mortality rate is thought to be between $2 \%$ and $5 \%$. Coronaviruses are zoonotic viruses and, in the present study, $70 \%$ of the participants answered this question correctly. ${ }^{15}$ Although no vaccine has been discovered yet, many vaccine studies are ongoing and COVID-19 is expected to become a vaccine-preventable disease. ${ }^{16,17}$ Even though no vaccine is currently available, nearly half of the participants in the present study stated that COVID-19 is a vaccine-preventable disease, which might be due to extrapolation of the knowledge of other flu-like viral infections. Many drugs are being tried for the treatment of COVID-19, and the effectiveness of these drugs has been demonstrated by some observational studies. ${ }^{16,18}$ Some of these drugs are antiretroviral drugs. In the present study, almost half of the participants were aware of this information.

In the study by Zhong et al. ${ }^{10}$, almost all of the participants stayed away from crowded places (96.4\%) and they always wore masks (98.0\%) when they went out. Because no positive COVID-19 cases had been diagnosed in Turkey at the time of our study, $72.6 \%$ of the participants stated that they were not wearing a mask.

The present study has some limitations. As it was conducted during a congress, it was limited to the congress participants and most of the participants were women. However, one of the strengths of the study is that the people attending the congress came from many different cities in Turkey and their age distribution was homogeneous. Another limitation is that attitudes and beliefs have not been evaluated in a standardized way and adequately, and in-depth interviews and multidimensional measurements may be required for this assessment.

\section{CONCLUSION}

It is important for pharmacists to have correct information about COVID-19 and to convey this knowledge to the public. Classical media and social media affect the attitudes of both society and health professionals. In addition, the high level of knowledge of individuals also positively affects their attitudes. Using media tools for accurate information is one of the basic conditions for preventing and controlling the spread of the disease. In this regard, studies evaluating the knowledge, beliefs, and attitudes of other healthcare professionals and other segments of society are required.

Conflicts of interest: No conflict of interest was declared by the authors. The authors alone are responsible for the content and writing of the paper.

\section{REFERENCES}

1. Zhu N, Zhang D, Wang W, Li X, Yang B, Song J, Song J, Zhao X, Huang B, Shi W, Lu R, Niu P, Zhan F, Ma X, Wang D, Xu W, Wu G, Gao GB, Tan W, Novel C. A Novel Coronavirus from Patients with Pneumonia in China, 2019. N Engl J Med. 2020;382:727-733.

2. World Health Organisation. Weekly Surveillance Report. Available at: http://www.euro.who.int/en/health-topics/health-emergencies/ coronavirus-covid-19/weekly-surveillance-report. Accessed: April 2, 2020.

3. Lu R, Zhao X, Li J, Niu P, Yang B, Wu H, Wang W, Song H5, Huang B, Zhu N, Bi Y,Ma X, Zhan F, Wang L, Hu T, Zhou H, Zhenhong Hu, Zhou W, Zhao L, Chen J, Meng Y, Wang J, Lin Y, Yuan J, Xie Z, Ma J, Liu WJ, Wang D, Xu W, Holmes EC, Gao GF, Wu G, Chen W, Shi W, Tan W. Genomic characterisation and epidemiology of 2019 novel coronavirus: implications for virus origins and receptor binding. Lancet. 2020;395:565-574.

4. Huang C, Wang Y, Li X, Ren L, Zhao J, Hu Y, Zhang L, Fan G, Xu J, Gu $X$, Cheng Z, Yu T, Xia J, Wei Y, Wu W, Xie X, Yin W, Li H, Liu M, Xiao Y, Gao H, Guo L, Xie J,Wang G, Jiang R, Gao Z, Jin Q, Wang J, Cao B. Clinical features of patients infected with 2019 novel coronavirus in Wuhan, China. Lancet. 2020;395:497-506.

5. Wu Z, McGoogan JM. Characteristics of and Important Lessons From the Coronavirus Disease 2019 (COVID-19) Outbreak in China: Summary of a Report of 72314 Cases From the Chinese Center for Disease Control and Prevention. JAMA. 2020.

6. Lim J, Jeon S, Shin HY, Kim MJ, Seong YM, Lee WJ, Choe KW, Kang YM, Lee B, Park SJ. Case of the Index Patient Who Caused Tertiary 
Transmission of COVID-19 Infection in Korea: the Application of Lopinavir/Ritonavir for the Treatment of COVID-19 Infected Pneumonia Monitored by Quantitative RT-PCR. J Korean Med Sci. 2020;35:e79.

7. T.C. Sağlık Bakanlığı Sağlık Bilgi Sistamleri Genel Müdürlüğü. Ankara; Sağlık İstatistikleri Yıllığı 2018; 2019.

8. Ghaibi S, Ipema H, Gabay M, American Society of Health System Pharmacists. ASHP guidelines on the pharmacist's role in providing drug information. Am J Health Syst Pharm. 2015;72:573-577.

9. Woods C, West C, Buettner P, Usher K. "Out of our control": living through Cyclone Yasi. Int J Qual Stud Health Well-being. 2014;9:19821.

10. Zhong BL, Luo W, Li HM, Zhang QQ, Liu XG, Li WT, Li Y. Knowledge, attitudes, and practices towards COVID-19 among Chinese residents during the rapid rise period of the COVID-19 outbreak: a quick online cross-sectional survey. Int J Biol Sci. 2020;16:1745-1752.

11. Adhikari SP, Meng S, Wu YJ, Mao YP, Ye RX, Wang QZ, Sun C, Sylvia S, Rozelle S, Raat H, Zhou HI. Epidemiology, causes, clinical manifestation and diagnosis, prevention and control of coronavirus disease (COVID-19) during the early outbreak period: a scoping review. Infect Dis Poverty. 2020;9:29.

12. Marchiori BE, Carraher CE, Stiles K. Understanding and overcoming business etiquette differences in Japan, Turkey, and the United States of America. Journal of Technology Management in China. 2014;9:274288.

13. National Health Commission of People's Republic of China. Prevent guideline of 2019-nCoV. 2020. Available at: http://www.nhc.gov.cn/xcs/ yqfkdt/202001/bc661e49b5bc487dba182f5c49ac445b.shtml. Accessed April 1, 2020.

14. Epidemiology Working Group for NCIP Epidemic Response, Chinese Center for Disease Control and Prevention. The epidemiological characteristics of an outbreak of 2019 novel coronavirus diseases (COVID-19) in China]. Zhonghua Liu Xing Bing Xue Za Zhi. 2020;41:145151.

15. Wu YC, Chen CS, Chan YJ. The outbreak of COVID-19: An overview. J Chin Med Assoc. 2020;83:217-220.

16. Li H, Zhou Y, Zhang M, Wang H, Zhao Q, Liu J. Updated approaches against SARS-CoV-2. Antimicrob Agents Chemother. 2020;64:483.

17. Ahmed SF, Quadeer AA, McKay MR. Preliminary Identification of Potential Vaccine Targets for the COVID-19 Coronavirus (SARS-CoV-2) Based on SARS-CoV Immunological Studies. Viruses. 2020;12:254.

18. Sarma P, Prajapat M, Avti P, Kaur H, Kumar S, Medhi B. Therapeutic options for the treatment of 2019-novel coronavirus: An evidencebased approach. Indian J Pharmacol. 2020;52:1-5. 